\title{
EFFECT OF MINERAL, BIO FERTILIZATION, HUMIC ACID AND THEIR INTERACTIONS ON SUGAR BEET \\ Ali Abdallah Ali Mekdad
}

Agronomy Department, Faculty of Agriculture, Fayoum University, El -Fayoum, Egypt

\section{ABSTRACT}

Two field experiments were conducted during 2014/15 and 2015/16 seasons to study the effect of three mineral nitrogen fertilizer levels i.e., 60,90 and $120 \mathrm{~kg} \mathrm{~N} / \mathrm{fed}$ and four biofertilization (without biofertilization, rhizobactrein, phosphorein and dual inoculation) and three foliar spraying levels with humic acid (water as a control, 12 and $24 \mathrm{~g} / \mathrm{l}$ ) on yield and its attributes of sugar beet variety Kawemira. The experimental design was a split-split plot in RCBD with three replications where mineral nitrogen fertilizer, biofertilization and foliar spraying with humic acid were allocated in the main, sub and sub-sub plots, respectively.

Results indicated that mineral nitrogen fertilizer and biofertilization with foliar spraying with humic acid had significant positive effect on yield, yield components and quality traits. The heaviest root fresh weight $(2.17 \mathrm{~kg} / \mathrm{plant})$, root yield $(39.77 \mathrm{t} / \mathrm{fed})$ and gross sugar yield (7.13 $\mathrm{t} / \mathrm{fed})\left(\mathrm{fed}=\right.$ feddan $\left.=4200 \mathrm{~m}^{2}\right)$ were obtained by the highest level of mineral nitrogen fertilizer $(120 \mathrm{~kg} \mathrm{~N} / \mathrm{fed})$, with application the mixture of rhizobactrein+ phosphorein as biofertilization with the highest concentration of foliar sprayed with humic acid $(24 \mathrm{~g} / \mathrm{l})$.

The results of regression analysis of yield and its attributes clarified that, there were four traits i.e. sucrose \%, root yield, root length and root fresh weight in the first season, while in the second season, the same traits except root length were significantly $(\mathrm{P} \leq 0.001)$ contributed to variation in gross sugar yield.

Keywords: Sugar beet, mineral fertilizer, biofertilization, humic acid, regression, yield and quality.

\section{INTRODUCTION}

Sugar beet (Beta vulgaris L.) crop has been an important position in Egyptian crop rotation as a winter crop either in fertile soils or poor ones. It is highly adapted to grow in the new reclaimed soils as economic crop, in addition to its limited water requirements. Compared with sugar cane, sugar beet requires lesser water quantity, where a kilogram of sugar requires about $1.4 \mathrm{~m}^{3}$ and 4.0 $\mathrm{m}^{3}$ water to be produced by sugar beet and sugar cane, respectively (Ouda, 2001). Approximately $77 \%$ of our local needs are produced locally, while the rest $(23 \%)$ is imported from foreign countries. Increasing cultivated area and sugar production from unit area and water unit is one of the important national targets to minimize gap between sugar consumption and production. Improving sugar beet production can be achieved through application of traditional and nontraditional methods (Hozayn et al., 2013).

Fayoum J. Agric. Res. \& Dev., Vol. 31, No.2, July, 2017 
Nitrogen fertilizer has a pronounced effect on the growth and chemical characteristics of the yield and quality of sugar beet. The economic yield of sugar beet, is thus closely relates to the sugar accumulation process. The filling process also depends on the photosynthetic efficacy of leaves, which is not only controlled by light intensity and temperature but also by mineral nutrition. So, nitrogen fertilization should be managed to produce high root yield with high sucrose percentage and purity levels. In this respect, Seadh, et al. 2007; Gobarah, et al. 2010; Nemeata Alla, et al. 2014; Mekdad, 2015 and Mekdad and Rady, 2016 reported that increasing nitrogen application as soil fertilizer recorded significantly increases in length, diameter and weight of roots as well as root, top and sugar yield $\mathrm{t} \mathrm{fad}^{-1}$ of sugar beet. On the other side, root quality traits of beet i.e. sucrose \%, juice purity and recoverable sugar percentages were significantly decreased by increasing nitrogen rates (Lauer, 1995; Seadh, et al. 2007; Gobarah, et al. 2010; Nemeata Alla, et al. 2014; Mekdad, 2015 and Mekdad and Rady, 2016). Moreover, impurities in terms of potassium, sodium and $\alpha$-amino nitrogen as well as sugar loss in molasses were significantly increased by increasing nitrogen levels (Seadh, et al. 2007; Mekdad, 2015 and Mekdad and Rady, 2016).

Biological fertilization of non-legume crops by $\mathrm{N}_{2}$-fixing bacteria had a great importance in recent years. The effect of inoculation had marked positive influence on the growth of plant, which reflects in yield increase. This increase might be due to the effect of $\mathrm{N}$ which was produced by bacteria species, in addition of some growth regulators like IAA and GA3 which stimulated growth. Many investigators applied biofertilizers to minimize the environmental pollution resulted from mineral fertilizers and also to reduce its coasts (Cakmakci, et al. 2001).

More recently, a real challenge faces the researchers to stop usage the high rates of agro-chemicals which negatively affect human health and environment by using nitrogen fixing bacteria and phosphate dissolving bacteria, which are important in plant nutrition by increasing $\mathrm{N}$ and $\mathrm{P}$ uptake by the plants, and playing a significant role as plant growth-promoting rhizobacteria in the biofertilization of crops (Sahin, et al. 2004). They added that, phosphorus biofertilizers could be help via increase the availability of accumulated phosphates for plant growth by solubilization, enhancing plant growth by the increasing the efficiency of biological nitrogen fixation and the availability of $\mathrm{Fe}, \mathrm{Zn}$ through production of plant growth promoting substances. In this regard, Kandil, et al. (2002) found that inoculation of sugar beet seeds with biofertilizer and $80 \mathrm{~kg} \mathrm{~N} /$ fed produced the highest weights of root and top yields. Badr (2006) showed that, inoculation seeds of sugar beet with bio-fertilizer in different combination with mineral fertilizer increased root dimensions, yields of root, top and sugar $\mathrm{t} / \mathrm{fed}$. On the other hand, the root quality (Sucrose and purity $\%$ ) were decreased by increasing nitrogen levels in combination with biofertilizer. Aboshady et al. (2009) mentioned that, microbial inoculation with

Fayoum J. Agric. Res. \& Dev., Vol. 31, No.2, July, 2017 
EFFECT OF MINERAL, BIO FERTILIZATION, HUMIC ACID

"Azotobacter chroococcum+Bacillus megatherium" significantly increased top and root yields and root fresh weight.

Humic acid treatment suggested to participate a beneficial role due to it is one of the natural antioxidants, the absorption of humic substances into the plant tissue resulting in various biochemical effects through elevate nutrient uptake and maintaining vitamins and amino acid level in plant tissues. Humic acid is used widely across the globe by agriculturists due to their several benefits i.e., stimulates the respiration rates, increase root and shoot growth on a fresh and dry weight basis on enhancement of plant root uptake of $\mathrm{P}, \mathrm{K}, \mathrm{Fe}, \mathrm{Cu}, \mathrm{Zn}$ and $\mathrm{Ca}$, stimulates plant enzymes and hormones- suppresses diseases, heat stress and frost damage by promoting antioxidants activity (Seydabadi and Armin 2014) they added that the mixture chloridazon + phenmedipham with humic acid produced highest root and sugar yields.

Shaban, et al. (2014) reported that, application of humic acid significantly increased on root yield by $(22.80 \%$ and $28.38 \%$ ), sugar yield by (26.56and $32.44 \%)$ and sucrose $\%$ by $(0.41$ and $0.61 \%)$, respectively in the $1^{\text {st }}$ and $2^{\text {nd }}$ seasons compared with untreated one. Rassam, et al. (2015) found that humic acid increased sucrose, root and sugar yield of sugar beet compared with control. EL-gamal, et al. (2016) reported that, foliar spraying with humic acid at $20 \mathrm{~g} / \mathrm{L}$ improved length, diameter and fresh weight of root as well as, sucrose $\%$, purity $\%$, root and sugar yields of sugar beet compared with control.

The main goal of the current trial was looking for the effect of mineral nitrogen fertilization and biofertilizers under foliar application with humic acid applied to sugar beet crop to get a high yield with a good quality in newly reclaimed soil, in addition to keep our environment clean and safe to live in.

\section{MATERIALS AND METHODS}

Two field experiments were conducted at the farm of the Faculty of Agriculture, Demo ( $\left.29^{\circ} 17^{`} \mathrm{~N} ; 30^{\circ} 53^{`} \mathrm{E}\right)$, Fayoum University, Egypt, during the two successive seasons of 2014/2015 and 2015/2016. The experimental soil was sandy loam with organic matter of $0.89 \%$, electical conductivity of $5.42 \mathrm{dS} / \mathrm{m}$ and $\mathrm{pH}$ of 7.96.The objective of this investigation was to study the effect of nitrogen fertilizer levels, inoculation of sugar beet seeds (Beta vulgaris L.) variety Kawemira with rhizobactrein and phosphorein singly or in combination under different levels of humic acid on yield, yield components and root quality. The recommended agricultural practices for growing sugar beet were followed except the factors under study which arranged in split-split plot in randomized complete block design with three replications. Ammonium nitrate $(33.5 \% \mathrm{~N})$ at three levels of nitrogen fertilizers (60, 90 and $120 \mathrm{~kg} \mathrm{~N} / \mathrm{fed})$ were arranged in the main plots, it was applied in three equal doses (at 4-6 leaf stage, before the $2^{\text {nd }}$ irrigation, and before the $3^{\text {rd }}$ irrigation). While four bio-fertilizer treatments. (without inoculation, rhizobactrein, phosphorein and dual inoculation) were randomly distributed in the sub plots. The sub-sub plots were occupied with three humic acid as foliar spraying (tap water, 12 and $24 \mathrm{~g} / \mathrm{l}$ ), were sprayed with

Fayoum J. Agric. Res. \& Dev., Vol. 31, No.2, July, 2017 
different used concentrations at 45, 75 and 105 days after planting date. Both rhizobactrein and phosphorein were produced by bio-fertilizers unit, General Organization of Agriculture Equalization Fund (G.O.A.E.F.), Agriculture Research Centre, Ministry of Agriculture, Giza Egypt. Humic acid: made in

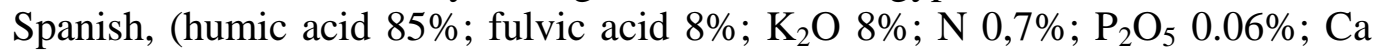
3.89\%; Mg 0.29\%; Fe 1.89\%; Mn 0.043\%; Zn 0.013; Cu 0.056\%; B 0.048 and soluble matter $95 \%$ ).

Each experimental basic unit included 5 ridges, $60 \mathrm{~cm}$ apart and $3.5 \mathrm{~m}$ long, comprising an area of $10.5 \mathrm{~m}^{2}$ (1/400fed). The preceding summer crop was corn (Zea mays L.) in both seasons. Experiments were sown on September $21^{\text {th }}$ and $27^{\text {th }}$ in the first and second seasons, respectively. Sugar beet was hand sown 3-5 balls/hill using dry sowing method on one side of the ridge in hills $20 \mathrm{~cm}$ apart. Plants were thinned to one plant/hill (35000 plants/fed) at the age of 35 days. Potassium fertilization was applied at the rate of $48 \mathrm{~kg} \mathrm{~K}_{2} \mathrm{O} / \mathrm{fed}$. as potassium sulphate $\left(48 \% \mathrm{~K}_{2} \mathrm{O}\right)$ in two equal doses the first after thinning and the second 21 days later.

At harvest, (after 210 days from sowing) a random sample of five guarded plants in each sub-sub plot was taken. Samples were carried immediately to laboratory where roots washed to remove the soil particles. Plants were separated into tops and roots. Root length $(\mathrm{cm})$, root diameter $(\mathrm{cm})$ and root fresh weight (kg/plant) were determined at harvest.

At harvest also, plants of all ridges from each sub-sub plot were harvested, cleaned, topped and weighed plus weight of five plant sample and then converted to estimate: Root yield ( $/$ /fed), top yield ( $t / f e d)$ and biological yield ( $t / f e d)$. It was calculated by adding root yield together with top yield ( $\mathrm{t} / \mathrm{fed})$.

Gross sugar yield ( $\mathrm{t} / \mathrm{fed}$ ), was estimated by multiplying root yield by gross sugar percentage. White sugar yield ( $\mathrm{t} / \mathrm{fed}$ ), was estimated by multiplying root yield by white sugar percentage. Losses sugar yield ( $t / f e d)$, was estimated by multiplying root yield by loss sugar percentage.

All traits were determined in Delta Sugar Company Limited Laboratories at ElHamoul, Kafr El-Sheikh Governorate according to the method of McGinnus (1971).

The traits of quality included: Gross sugar \%: Juice sugar content was determined according to McGinnus (1971). White sugar \%: Extractable sugar content (white sugar) of beets was calculated according to Harvey and Dotton (1993) as follows:

$\mathrm{ZB}=$ pol-[0.343(K+NA) + $0.094 \mathrm{AmN}+0.29]$

Where: $\mathrm{ZB}=$ extractable sugar content $(\%$ per beet $)$ or white sugar. Pol = gross sugar $\%$. AmN $=\alpha$-amino-N determined by the "blue number method"

Loss sugar \%: Loss sugar $\%=$ gross sugar $\%$ - white sugar $\%$

Juice purity percentage: Juice purity $\%(\mathrm{Qz})=\mathrm{ZB} / \mathrm{Pol} \times 100$.

Fayoum J. Agric. Res. \& Dev., Vol. 31, No.2, July, 2017 
EFFECT OF MINERAL, BIO FERTILIZATION, HUMIC ACID.

The soluble non-sugars (potassium, sodium and alpha-amino nitrogen in meq/100 $\mathrm{g}$ of beet) in roots were determined by an Automatic Sugar Polarimetric.

All obtained data were statistically analyzed according to the technique of analysis of variance (ANOVA) for the split-split plot design as published by Gomez and Gomez (1984), using MSTAT-C (Michogen, USA), and LSD at 5\% levels of probability was used to test the differences between treatment means.

\section{RESULTS AND DISCUSSION}

\section{A- Effect of nitrogen fertilizer levels:}

Data in table (1) reveal that nitrogen fertilizer levels exerted significant effects on sugar beet root length and diameter as well as root fresh weight in $1^{\text {st }}$ and $2^{\text {nd }}$ seasons of the study. The highest nitrogen level $(120 \mathrm{~kg} \mathrm{~N} / \mathrm{fed})$ exhibited higher values for such traits reached $45.49 \& 40.97 \%$ on root length, $26.75 \&$ $62.35 \%$ on root diameter, and $50.41 \& 84.16 \%$ on root fresh weight in $1^{\text {st }}$ and $2^{\text {nd }}$ seasons, respectively, comparable with $60 \mathrm{~kg} \mathrm{~N} / \mathrm{fed}$ nitrogen level. Amin, et al. (2013); Nemeata Alla, et al. (2014); Mekdad (2015) and Mekdad and Rady (2016) recorded similar tendency.

Nitrogen fertilizer levels caused significant effects on all yield characters i.e. root, top, biological and loss sugar yield in the two growing seasons, and gross sugar yield in the second one (Table 1 and 3). The highest values of root yield (33.41 and $35.05 \mathrm{t} /$ fed), top yield (12.33 and $13.97 \mathrm{t} / \mathrm{fed}$ ), biological yield (45.74 and $49.01 \mathrm{t} / \mathrm{fed})$, loss sugar yield (1.08 and $2.13 \mathrm{t} / \mathrm{fed})$ in the first and second season, respectively, but gross sugar yield $(6.47 \mathrm{t} / \mathrm{fed})$ in the $2^{\text {nd }}$ season were produced from fertilizing

Fayoum J. Agric. Res. \& Dev., Vol. 31, No.2, July, 2017 
Table (1): Effect of mineral nitrogen, biofertilizer, humic acid and their interactions on root length, root diameter. root fresh weight, root yield, top yield and biological yield of sugar beet during 2014/15 and 2015/16 seasons.

\begin{tabular}{|c|c|c|c|c|c|c|c|c|c|c|c|c|}
\hline \multirow{2}{*}{ Treatments } & \multicolumn{2}{|c|}{ Root length $\mathrm{cm}$} & \multicolumn{2}{|c|}{ Root diameter cm } & \multicolumn{2}{|c|}{ Root fresh weight kg/p } & \multicolumn{2}{|c|}{ Root yield t/fed } & \multicolumn{2}{|c|}{ Top yield $\mathrm{t} / \mathrm{fed}$} & \multicolumn{2}{|c|}{ Biological yield $\mathrm{t} / \mathrm{fed}$} \\
\hline & $2014 / 15$ & $2015 / 16$ & $2014 / 15$ & $2015 / 16$ & $2014 / 15$ & $2015 / 16$ & $2014 / 15$ & $2015 / 16$ & $2014 / 15$ & $2015 / 16$ & $2014 / 15$ & $2015 / 16$ \\
\hline & \multicolumn{12}{|c|}{ A- Nitrogen } \\
\hline $60 \mathrm{~kg} \mathrm{~N} / \mathrm{fed}$ & 26.36 & 27.19 & 11.55 & 10.20 & 1.21 & 1.01 & 26.66 & 21.76 & 8.38 & 7.53 & 35.04 & 29.29 \\
\hline $90 \mathrm{~kg} \mathrm{~N} / \mathrm{fed}$ & 29.13 & 32.55 & 12.94 & 13.77 & 1.45 & 1.46 & 29.03 & 25.59 & 9.34 & 11.01 & 38.37 & 36.61 \\
\hline $120 \mathrm{~kg} \mathrm{~N} / \mathrm{fed}$ & 38.35 & 38.33 & 14.64 & 16.56 & 1.82 & 1.86 & 33.41 & 35.05 & 12.33 & 13.97 & 45.74 & 49.01 \\
\hline \multirow[t]{2}{*}{ LSD (5\%) } & 0.15 & 0.83 & 0.08 & 0.36 & 0.01 & 0.22 & 0.22 & 2.27 & 0.09 & 0.86 & 0.30 & 2.80 \\
\hline & \multicolumn{12}{|c|}{ B- Biofertilizer } \\
\hline Without & 28.99 & 31.04 & 11.53 & 12.49 & 1.08 & 1.33 & 25.21 & 25.65 & 8.62 & 10.03 & 33.83 & 35.68 \\
\hline Rhizobacterin & 31.17 & 32.76 & 13.81 & 13.69 & 1.61 & 1.45 & 30.43 & 27.45 & 10.53 & 10.86 & 40.96 & 38.31 \\
\hline \begin{tabular}{|l|} 
Phosphorin \\
\end{tabular} & 30.49 & 32.13 & 12.27 & 13.24 & 1.51 & 1.38 & 29.53 & 27.05 & 9.35 & 10.58 & 38.89 & 37.63 \\
\hline $\begin{array}{c}\text { Rhizobacterin+ } \\
\text { Phosphorin }\end{array}$ & 34.46 & 34.83 & 14.56 & 14.61 & 1.77 & 1.61 & 33.62 & 29.73 & 11.56 & 11.88 & 45.18 & 41.61 \\
\hline \multirow[t]{2}{*}{ LSD (5\%) } & 0.21 & 0.24 & 0.10 & 0.09 & 0.01 & 0.04 & 0.18 & 0.56 & 0.10 & 0.19 & 0.25 & 0.67 \\
\hline & \multicolumn{12}{|c|}{ C- Humic acid } \\
\hline $\mathbf{0}$ & 30.29 & 32.05 & 12.45 & 13.15 & 1.30 & 1.40 & 28.49 & 26.96 & 9.28 & 10.57 & 37.76 & 37.53 \\
\hline $12 \mathrm{~g} / \mathrm{l}$ & 31.33 & 32.67 & 13.14 & 13.51 & 1.54 & 1.45 & 29.68 & 27.41 & 10.15 & 10.84 & 39.83 & 38.25 \\
\hline $24 \mathrm{~g} / \mathrm{l}$ & 32.22 & 33.35 & 13.53 & 13.87 & 1.63 & 1.48 & 30.93 & 28.03 & 10.62 & 11.10 & 41.55 & 39.13 \\
\hline \multirow[t]{2}{*}{ LSD (5\%) } & 0.11 & 0.11 & 0.03 & 0.05 & 0.01 & \begin{tabular}{l|l}
0.01 \\
\end{tabular} & 0.09 & 0.13 & 0.11 & 0.03 & 0.09 & 0.13 \\
\hline & \multicolumn{12}{|c|}{ D- Interactions } \\
\hline LSD (5\%)AB & 0.36 & ns & $\mathrm{ns}$ & 0.11 & 0.01 & \begin{tabular}{l|l}
0.06 \\
\end{tabular} & ns & 0.97 & $\mathrm{~ns}$ & $\mathrm{~ns}$ & $\mathrm{~ns}$ & 1.16 \\
\hline AC & $\mathrm{ns}$ & 0.19 & $\mathrm{~ns}$ & $\mathrm{~ns}$ & 0.01 & $\mathrm{~ns}$ & $\mathrm{~ns}$ & 0.23 & $\mathrm{~ns}$ & 0.05 & $\mathrm{~ns}$ & 0.23 \\
\hline BC & 0.22 & 0.22 & 0.06 & 0.10 & 0.01 & ns & 0.17 & 0.26 & 0.05 & 0.05 & 0.19 & 0.26 \\
\hline $\mathbf{A B C}$ & 0.39 & 0.38 & ns & 0.17 & 0.02 & ns & $\mathrm{ns}$ & 0.46 & ns & ns & ns & 0.45 \\
\hline
\end{tabular}

ns - non-significant 
EFFECT OF MINERAL, BIO FERTILIZATION, HUMIC ACID.......... 41 Table (2): Effect of mineral nitrogen, biofertilizer, humic acid and their interactions on percentage of sucrose, sodium, potassium, alpha amino nitrogen, extractable sugar and purity of sugar beet during 2014/15 and 2015/16 seasons.

\begin{tabular}{|c|c|c|c|c|c|c|c|c|c|c|c|c|}
\hline \multirow{2}{*}{ Treatments } & \multicolumn{2}{|c|}{ Sucrose \% } & \multicolumn{2}{|c|}{$\mathrm{Na} \%$} & \multicolumn{2}{|c|}{$\mathbf{K} \%$} & \multicolumn{2}{|c|}{$\alpha$-amino N \% } & \multicolumn{2}{|c|}{$\begin{array}{c}\text { Extractable sugar } \\
\%\end{array}$} & \multicolumn{2}{|c|}{ Purity \% } \\
\hline & $2014 / 15$ & $2015 / 16$ & $2014 / 15$ & $2015 / 16$ & $2014 / 15$ & $2015 / 16$ & $2014 / 15$ & $2015 / 16$ & $2014 / 15$ & $2015 / 16$ & $2014 / 15$ & $2015 / 16$ \\
\hline & \multicolumn{12}{|c|}{ A- Nitrogen } \\
\hline $60 \mathrm{~kg} \mathrm{~N} / \mathrm{fed}$ & 21.26 & 22.87 & 1.29 & 1.25 & 2.82 & 1.44 & 0.91 & 0.97 & 19.48 & 20.56 & 91.56 & 89.84 \\
\hline $90 \mathrm{~kg} \mathrm{~N} / \mathrm{fed}$ & 21.06 & 20.88 & 2.72 & 1.87 & 3.82 & 2.51 & 1.32 & 1.48 & 18.40 & 16.93 & 87.00 & 80.90 \\
\hline $120 \mathrm{~kg} \mathrm{~N} / \mathrm{fed}$ & 18.03 & 18.47 & 3.41 & 3.02 & 4.77 & 3.47 & 1.51 & 1.64 & 14.80 & 12.42 & 81.98 & 67.09 \\
\hline LSD (5\%) & 1.56 & 1.22 & 0.11 & 0.19 & 0.24 & 0.13 & 0.03 & 0.08 & 1.64 & 1.14 & 0.85 & 1.55 \\
\hline & \multicolumn{12}{|c|}{ B- Biofertilizer } \\
\hline Without & 20.83 & 21.59 & 2.27 & 1.81 & 3.51 & 2.17 & 1.18 & 1.25 & 18.45 & 18.02 & 88.32 & 82.70 \\
\hline Rhizobacterin & 19.86 & 20.70 & 2.49 & 2.03 & 3.75 & 2.44 & 1.24 & 1.35 & 17.32 & 16.64 & 86.92 & 79.57 \\
\hline Phosphorin & 21.04 & 20.88 & 2.46 & 1.98 & 3.68 & 2.41 & 1.22 & 1.34 & 18.53 & 16.91 & 87.37 & 80.14 \\
\hline \begin{tabular}{|c|} 
Rhizobacterin+ \\
Phosphorin
\end{tabular} & 18.74 & 19.78 & 2.27 & 2.37 & 4.27 & 2.86 & 1.36 & 1.50 & 15.95 & 14.98 & 84.77 & 74.71 \\
\hline \begin{tabular}{|l|} 
LSD (5\%) \\
\end{tabular} & 1.37 & 0.23 & 0.0 & 0.08 & 0.10 & 0.09 & 0.02 & 0.04 & 1.37 & 0.22 & 0.44 & 0.55 \\
\hline & \multicolumn{12}{|c|}{ C- Humic acid } \\
\hline $\mathbf{0}$ & 19.52 & 20.47 & 2.56 & 2.09 & 3.94 & 2.62 & 1.29 & 1.39 & 16.88 & 16.17 & 86.14 & 78.06 \\
\hline $12 \mathrm{~g} / \mathrm{l}$ & 20.70 & 20.73 & 2.48 & 2.05 & 3.79 & 2.48 & 1.25 & 1.36 & 18.14 & 16.62 & 87.01 & 79.26 \\
\hline $24 \mathrm{~g} / \mathrm{l}$ & 20.13 & 21.03 & 2.37 & 2.01 & 3.68 & 2.31 & 1.21 & 1.33 & 17.65 & 17.12 & 87.39 & 80.52 \\
\hline LSD (5\%) & Ns & 0.05 & ns & 0.01 & 0.03 & 0.05 & 0.01 & 0.02 & $\mathrm{~ns}$ & 0.07 & 0.28 & 0.26 \\
\hline & \multicolumn{12}{|c|}{ D- Interactions } \\
\hline LSD (5\%)AB & ns & $\mathrm{ns}$ & $\mathrm{n}$ & 0.14 & 0.18 & 0.16 & 0.03 & 0.06 & ns & 0.38 & $\mathrm{~ns}$ & 0.96 \\
\hline $\mathrm{AC}$ & $\mathrm{ns}$ & $\mathrm{ns}$ & $\mathrm{ns}$ & 0.02 & ns & $\mathrm{ns}$ & 0.01 & $\mathrm{Ns}$ & $\mathrm{ns}$ & $\mathrm{ns}$ & $\mathrm{ns}$ & $\mathrm{ns}$ \\
\hline BC & ns & ns & ns & $\mathrm{ns}$ & 0.05 & ns & 0.01 & Ns & ns & ns & ns & ns \\
\hline $\mathbf{A B C}$ & ns & ns & ns & ns & ns & ns & 0.02 & Ns & ns & ns & $\mathrm{ns}$ & $\mathrm{ns}$ \\
\hline
\end{tabular}

ns - non-significant

Fayoum J. Agric. Res. \& Dev., Vol. 31, No.2, July, 2017 
Table (3): Effect of mineral nitrogen, biofertilizer, humic acid and their interactions on of loss sugar percentage, and yield of gross, extractable and loss sugar of sugar beet during $2014 / 15$ and 2015/16 seasons.

\begin{tabular}{|c|c|c|c|c|c|c|c|c|}
\hline \multirow{2}{*}{ Treatments } & \multicolumn{2}{|c|}{ Loss sugar \% } & \multicolumn{2}{|c|}{ Gross sugar yield t/fed } & \multicolumn{2}{|c|}{$\begin{array}{c}\text { Extractable sugar } \\
\text { yield t/fed }\end{array}$} & \multicolumn{2}{|c|}{ Loss sugar yield $t /$ fed } \\
\hline & $2014 / 15$ & $2015 / 16$ & $2014 / 15$ & $2015 / 16$ & $2014 / 15$ & $2015 / 16$ & $2014 / 15$ & $2015 / 16$ \\
\hline & \multicolumn{8}{|c|}{ A- Nitrogen } \\
\hline $60 \mathrm{~kg} \mathrm{~N} / \mathrm{fed}$ & 1.78 & 2.31 & 5.65 & 4.97 & 5.17 & 4.47 & 0.48 & 0.51 \\
\hline $90 \mathrm{~kg} \mathrm{~N} / \mathrm{fed}$ & 2.66 & 3.95 & 6.11 & 5.34 & 5.33 & 4.32 & 0.77 & 1.02 \\
\hline $120 \mathrm{~kg} \mathrm{~N} / \mathrm{fed}$ & 3.23 & 6.05 & 6.01 & 6.47 & 4.92 & 4.34 & 1.08 & 2.13 \\
\hline \multirow[t]{2}{*}{ LSD $(5 \%)$} & 0.08 & 0.20 & ns & 0.57 & ns & ns & 0.02 & 0.12 \\
\hline & \multicolumn{8}{|c|}{ B- Biofertilizer } \\
\hline Without & 2.38 & 3.57 & 5.22 & 5.45 & 4.60 & 4.47 & 0.61 & 0.98 \\
\hline Rhizobacterin & 2.55 & 4.06 & 6.01 & 5.59 & $5 . .22$ & 4.51 & 0.79 & 1.20 \\
\hline Phosphorin & 2.51 & 3.98 & 6.18 & 5.56 & 5.43 & 4.39 & 0.76 & 1.16 \\
\hline $\begin{array}{c}\text { Rhizobacterin+ } \\
\text { Phosphorin }\end{array}$ & 2.80 & 4.80 & 6.27 & 5.77 & 5.31 & 5.24 & 0.95 & 1.53 \\
\hline \multirow[t]{2}{*}{ LSD (5\%) } & 0.04 & 0.10 & 0.42 & 0.09 & 0.42 & 0.08 & 0.01 & 0.04 \\
\hline & \multicolumn{8}{|c|}{ C- Humic acid } \\
\hline $\mathbf{0}$ & 2.64 & 4.29 & 5.50 & 5.42 & 4.73 & 4.17 & 0.77 & 1.25 \\
\hline $12 \mathrm{~g} / \mathrm{l}$ & 2.56 & 4.11 & 6.09 & 5.58 & 5.32 & 4.36 & 0.78 & 1.22 \\
\hline $24 \mathrm{~g} / \mathrm{l}$ & 2.48 & 3.91 & 6.17 & 5.78 & 5.38 & 4.59 & 0.79 & 1.19 \\
\hline \multirow[t]{2}{*}{ LSD (5\%) } & 0.02 & 0.05 & 0.34 & 0.03 & 0.34 & 0.03 & Ns & ns \\
\hline & \multicolumn{8}{|c|}{ D- Interactions } \\
\hline LSD (5\%)AB & 0.06 & 0.18 & ns & 0.16 & ns & ns & 0.02 & 0.07 \\
\hline $\mathrm{AC}$ & $\mathrm{ns}$ & $\mathrm{ns}$ & ns & 0.05 & ns & 0.05 & 0.01 & ns \\
\hline BC & 0.02 & $\mathrm{~ns}$ & ns & 0.06 & ns & 0.06 & 0.01 & $\mathrm{~ns}$ \\
\hline $\mathbf{A B C}$ & 0.03 & ns & ns & 0.10 & ns & ns & 0.02 & $\mathrm{~ns}$ \\
\hline
\end{tabular}

ns - non-significant

Table (4): Correlation coefficient ( $r$ ), coefficient of determination $\left(R^{2}\right)$ and standard error of the estimates (SEE) for predicting gross sugar yield $(t /$ fed) in 2014/15 and 2015/16 seasons.

\begin{tabular}{|c|c|c|c|c|c|}
\hline Season & $\mathbf{R}$ & $\mathbf{R}^{2}$ & SEE & Sig. & Fitted equation \\
\hline $2014 / 15$ & 0.998 & 0.996 & 0.073 & $* * *$ & $\begin{array}{c}\text { Gross sugar yield }=-5.90+0.301 \text { sucrose \% + } \\
0.196 \text { root yield }-0.001 \text { root length +0.117 root fresh weight }\end{array}$ \\
\hline $2015 / 16$ & 0.996 & 0.993 & 0.069 & $* * *$ & $\begin{array}{c}\text { Gross sugar yield }=-5.255+0.176 \text { root yield+ } \\
0.264 \text { sucrose } \%+0.367 \text { root fresh weight }\end{array}$ \\
\hline
\end{tabular}

Fayoum J. Agric. Res. \& Dev., Vol. 31, No.2, July, 2017 
EFFECT OF MINERAL, BIO FERTILIZATION, HUMIC ACID.

beet plants with $120 \mathrm{~kg} \mathrm{~N} / \mathrm{fed}$. The lowest values of former yield characteristics were obtained from $(60 \mathrm{~kg} \mathrm{~N} / \mathrm{fed})$ in the two growing seasons. The increase in yield characters due to application of nitrogen fertilization can be explained through the fact that nitrogen has a vital role in building up metabolites, activating enzymes and enhanced root length, diameter as well as root fresh weight and finally root and sugar yields per unit area. Seadh, et al. (2007); Shewate, et al. (2008); El-Sarag (2009); Zhang, et al. (2009); Attia, et al. (2011); Amin, et al. (2013); Nemeata Alla, et al., (2014); Mekdad (2015) and Mekdad and Rady (2016) recorded similar tendency.

Significant differences on all root quality traits were obtained due to nitrogen fertilizer levels in both seasons (Table, 2). The highest sucrose (21.26 and $22.87 \%$ ), extractable sugar (19.48 and $20.56 \%$ ) and purity (91.56 and 89.84 $\%$ ) were recorded by the minimum level of nitrogen $60 \mathrm{~kg} \mathrm{~N} / \mathrm{fed}$ in both seasons. On the other side, the highest values of impurities in terms of $\mathrm{Na}, \mathrm{K}$ and $\alpha$-amino $\mathrm{N}$ as well as, loss sugar percentages were recorded by the maximum level of nitrogen $(120 \mathrm{~kg} \mathrm{~N} / \mathrm{fed})$ in the both seasons. This result is consistent with the previous researchers of (Seadh, et al. 2007; Stevens, et al. 2007; Gobarah, et al. 2010; Amin, et al. 2013; Nemeata Alla, et al. 2014; Mekdad, 2015 and Mekdad and Rady, 2016). These results may be due to the reason that high levels of nitrogen fertilizers application can be ascribed to its role in increasing root weight and diameter, tissue water content as well as increasing soluble nonsugar compounds in root juice and they interfere with sugar extraction which reflected by raising the percentage of sugar loss to molasses and consequently reducing sugar extractable $\%$.

\section{B- Effect of biofertilization treatments}

Biofertilization treatments caused significant effects on root length and root diameter as well as root fresh weights as shown in table (1). Application the mixture of rhizobactrein+ phosphorein produced the highest values of yield attributes (root length, root diameter and root fresh weights) in both seasons. From obtained results under the environmental conditions of this research, it could be observed that using of rhizobacterin biofertilizer either alone or in the mixture with phosphorien surpassed control and phosphorien biofertilizer alone during both seasons. However, the lowest values of the former parameters were resulted from control treatment (without biofertilization) in both seasons. This increase in yield attributes as a result of application biofertilizers particularly rhizobacterin may be due to its role in nitrogen fixation via free living bacteria which reduce the soil $\mathrm{pH}$ especially in the rhizosphere which led to increase the availability of most essential macro and micro-nutrients as well as excretion some growth substances such as IAA and GA3 which play an important role in formation a large and active root system and, therefore, increasing nutrient uptake, which stimulate establishment and vegetative growth, hence increasing root parameters. Many investigators confirm this conclusion i.e. Kandil, et al.

Fayoum J. Agric. Res. \& Dev., Vol. 31, No.2, July, 2017 
(2002); Ramadan, et al. (2003); Badawi, et al. (2004); Gobarah, et al. (2011) and Amin, et al. (2013).

Data in Table (1 and 3) show that root, top, biological, gross sugar, extractable sugar and loss sugar yields/fed were significantly responded to biofertilization treatments in both seasons. Noteworthy, application the mixture of rhizobacterin + phosphorien biofertilizers yielded the highest values of root yield (33.62 and $29.73 \mathrm{t} / \mathrm{fed}$ ), top yield (11.56 and $11.88 \mathrm{t} / \mathrm{fed})$, biological yield (45.18 and $41.61 \mathrm{t} / \mathrm{fed}$ ), gross sugar yield (6.27 and $5.77 \mathrm{t} / \mathrm{fed})$, extractable sugar yield (5.31 and $4.24 \mathrm{t} / \mathrm{fed})$ and loss sugar yield (0.95 and $1.53 \mathrm{t} / \mathrm{fed})$ in the first and second seasons, respectively. Concerning application of rhizobacterin, it's ranked after aforementioned treatment, respectively with respecting their effect on former parameters in the two seasons. On the other hand, control treatment (without biofertilization) resulted in the lowest means of these yield traits. This effect of biofertilization treatments expressly rhizobacterin biofertilizer may be ascribed to its role in improving plant growth, vigor of plant and yields through fixing atmospheric nitrogen and mineralization and/or mineralizing organic compounds as well as release of certain growth regulators, stimulatory compounds and nutrients in soil by the introduced organisms. Similar results were in coincidence with the present ones as reported by Badawi, et al. (2004); Gobarah, et al. (2011) and Amin, et al. (2013).

Data in Table (2 and 3) clear that application of biofertilization treatments were associated with negatively significant effect on sucrose, extractable sugar, purity, impurities in terms of ( $\mathrm{Na}, \mathrm{K}$ and $\alpha$-amino $\mathrm{N}$ ), as well as loss sugar in molasses percentages in both seasons. The decrease in quality parameters due to bio fertilizer can be ascribed to its role in increasing root weight as well as increasing non-sucrose substances such as proteins and alpha amino acid, and hence decreasing sucrose content in roots (Sahin, et al., 2004). These results are in good agreement with those reported by Gobarah, et al. (2011) and Amin, et al. (2013).

\section{C- Effect of foliar spray with humic acid:}

Results given in table (1) indicate that application of $24 \mathrm{~g} / \mathrm{l}$ foliar spray with humic acid significantly increased root length by $(6.37 \%$ and $4.06 \%)$, root diameter by $(8.67 \%$ and $5.48 \%)$ and root fresh weight by $(25.38$ and $5.71 \%)$ in the $1^{\text {st }}$ and $2^{\text {nd }}$ seasons, respectively compare with untreated plants. This may be due to promoting growth and nutrient uptake of plants by addition of humic substances which affect membrane permeability Zientara (1983) and Shaban, et al. (2014). A similar trend was found by EL-gamal, et al. (2016) who showed that root fresh weight of sugar beet was affected by the level of humic acid 25 $\mathrm{g} / \mathrm{L}$ and the maximum value (1250 g/plant ) was obtained from humic application and the lowest value (1017 g/plant) was observed when humic acid was not applied. Türkmen et al. (2005) reported that humic acid application positively affected the parameters of plant grown in salinity condition.

Fayoum J. Agric. Res. \& Dev., Vol. 31, No.2, July, 2017 
Data in table (1 and 3) clear that a significant effect of foliar spray with humic acid was found for root, top, biological, gross sugar and extractable sugar yields $\mathrm{t} /$ fed. Application of $24 \mathrm{~g} / \mathrm{l}$ humic acid was significantly increased effected on root yield by (8.56 and $3.97 \%$ ), top yield by (14.44 and 5.01\%), biological yield by (10.04 and $4.26 \%)$, gross sugar yield by (12.19 and 6.63\%) and extractable sugar yield by $(13.74$ and $10.07 \%)$, respectively in the $1^{\text {st }}$ and $2^{\text {nd }}$ seasons compared with untreated one. These results may be due to that humic substances enhance the uptake of some nutrients, and improve the plant characteristics. This was reflected in the growth characteristics and occurred positive effect on the final production of sugar beet plants. In this respect, Mehdi, et al. (2013) and Shaban, et al. (2014) reported that, root and sugar yield were strongly affected by humic acid, where humic acid increased root and sugar yield compared with untreated plant.

Data in table (2) clear that a significant effect of foliar spray with humic acid was found for $\mathrm{K}, \alpha$-amino $\mathrm{N}$, purity and loss sugar in molasses $\%$ in both seasons, and sucrose, extractable sugar and $\mathrm{Na} \%$ only in the first season. Applying $24 \mathrm{~g} / 1$ of humic acid was accompanied by increased percentage of sucrose, extractable sugar and purity \% compared with the control. On the other hand, Applying $24 \mathrm{~g} / 1$ of humic acid was accompanied by decreased impurities in terms of $\mathrm{Na}, \mathrm{K}$ and $\alpha$-amino $\mathrm{N} \%$, as well as loss sugar in molasses compared with the control. In this respect, EL-gamal, et al. (2016) reported that, sucrose and purity percentage of sugar beet were strongly increased by humic acid.

\section{D- INTERACTION EFFECTS}

D-1. Effect of the bilateral interaction between the three mineral nitrogen fertilizer and four biofertilization levels: Data illustrated in tables (1,2 and 3) reveal that root fresh weight (kg/plant), $\mathrm{K}, \alpha$-amino $\mathrm{N}$, loss sugar $\%$ and loss sugar yield ( $\mathrm{t} / \mathrm{fed}$ ) were significantly affected by the interaction between application of three mineral nitrogen fertilizer and four biofertilization levels in both seasons, and root length in $1^{\text {th }}$ season, but root diameter, root yield, biological yield, $\mathrm{Na}$, extractable sugar, purity and gross sugar yield in the second one. The highest root length, diameter and fresh weight, yield in terms of root, biological and gross sugar were recorded in fertilized with level of $120 \mathrm{~kg} \mathrm{~N} / \mathrm{fed}$ as mineral fertilizers and dual inoculation. These results are accomplished with those reported by Kandil, et al. (2002); Ramadan, et al. (2003) and Gobarah, et al., (2011) who stated that, this increment in yield characters were due to the interaction between bio-and mineral fertilizer.

D-2. Effect of the bilateral interaction between the three mineral nitrogen fertilizer levels and three foliar spray with humic acid: Results in tables (1,2 and 3 ) indicat that root fresh weight ( $\mathrm{kg} / \mathrm{plant}), \alpha$-amino $\mathrm{N} \%$ and loss sugar yield (t/fed) in the first season, and root length $(\mathrm{cm}), \mathrm{Na} \%$, yield in terms of root, top, biological, gross and extractable sugar (t/fed) in the second season were significantly affected by the interaction between application of the three mineral nitrogen fertilizer levels and three foliar spray with humic acid. The highest root length and root fresh

Fayoum J. Agric. Res. \& Dev., Vol. 31, No.2, July, 2017 
weight, as well as yields in terms of root, top, biological, gross and extractable sugar were recorded from the foliar sprayed application with humic acid $24 \mathrm{~g} / \mathrm{l}$ and soil $\mathrm{N}$ fertilization by $120 \mathrm{~kg} \mathrm{~N} / \mathrm{fed}$. These results are in agreement with those obtained by El-Hassanin, et al. (2016). They found that the highest top, root and sugar yields recorded from the foliar application with fulvic acid and the highest soil $\mathrm{N}$ fertilization. Shaban, et al. (2014) reported that the interaction effect between inorganic and organic nitrogen fertilization showed a significant effect on root and sugar yields and sucrose \%, the highest values of all the previous traits were obtained by $100 \mathrm{~kg} \mathrm{~N} /$ fed and $10 \mathrm{~kg} /$ fed humic acid.

D-3. Effect of the bilateral interaction between four biofertilization and three foliar spray with humic acd: Data illustrated in tables (1,2 and 3) reveal that the mean root length and diameter $(\mathrm{cm})$ and yield in terms of root, top and biological (t/fed) in 2014/15 and 2015/16 seasons, besides root fresh weight (kg/plant), K, $\alpha$ amino $\mathrm{N}$, loss sugar in molasses $\%$ and loss sugar yield (t/fed) in the first season, in addition to, gross and extractable sugar yield (t/fed) in the second season were significantly affected by the interaction between application of four biofertilization and foliar spray with humic acid levels.

D-4. Effect of the trilateral interaction among the three levels of mineral nitrogen fertilizer, four levels of biofertilization and three levels of foliar spray with humic acid: The data presented in tables (1,2 and 3) show the differences root length (cm) in 2014/15 and 2015/16 seasons, as well as root fresh weigh (kg/plant), $\alpha$-amino $\mathrm{N}$, loss sugar in molasses $\%$ and loss sugar yield ( $\mathrm{t} / \mathrm{fed}$ ) in the first season,

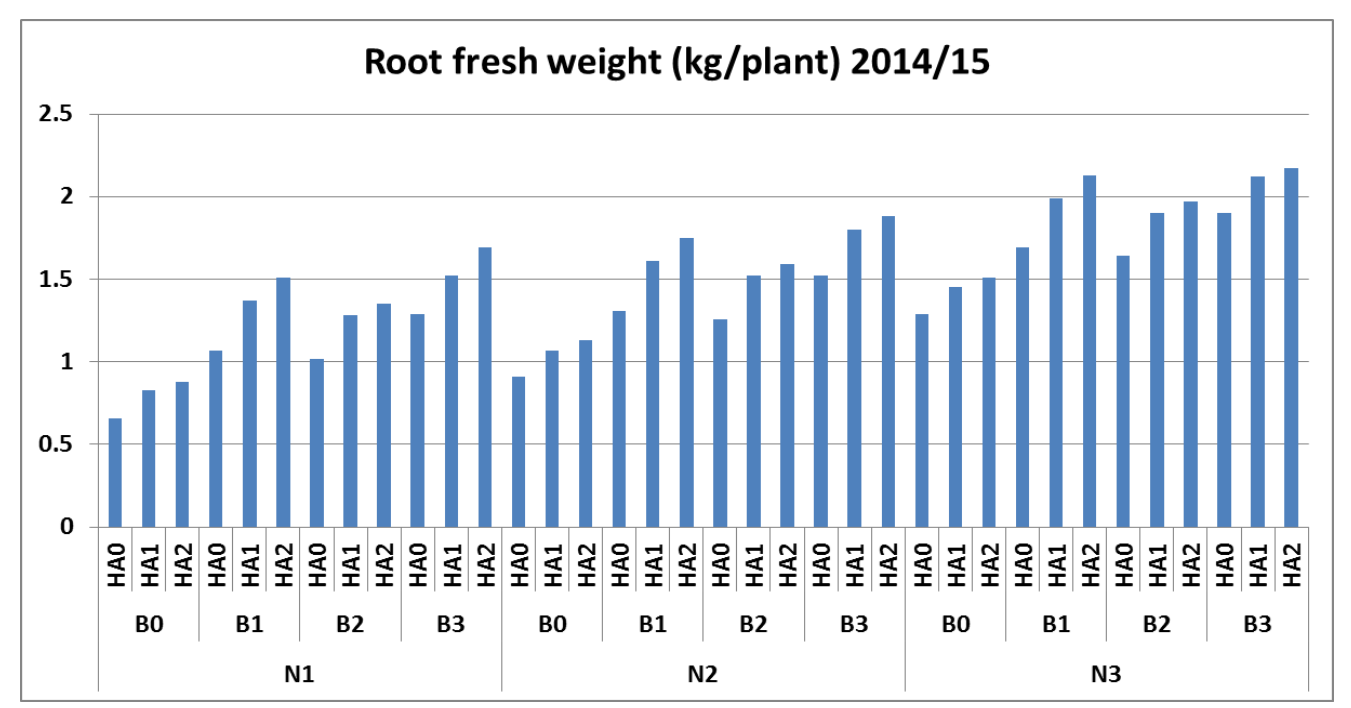

Fig. (1)

Fayoum J. Agric. Res. \& Dev., Vol. 31, No.2, July, 2017 


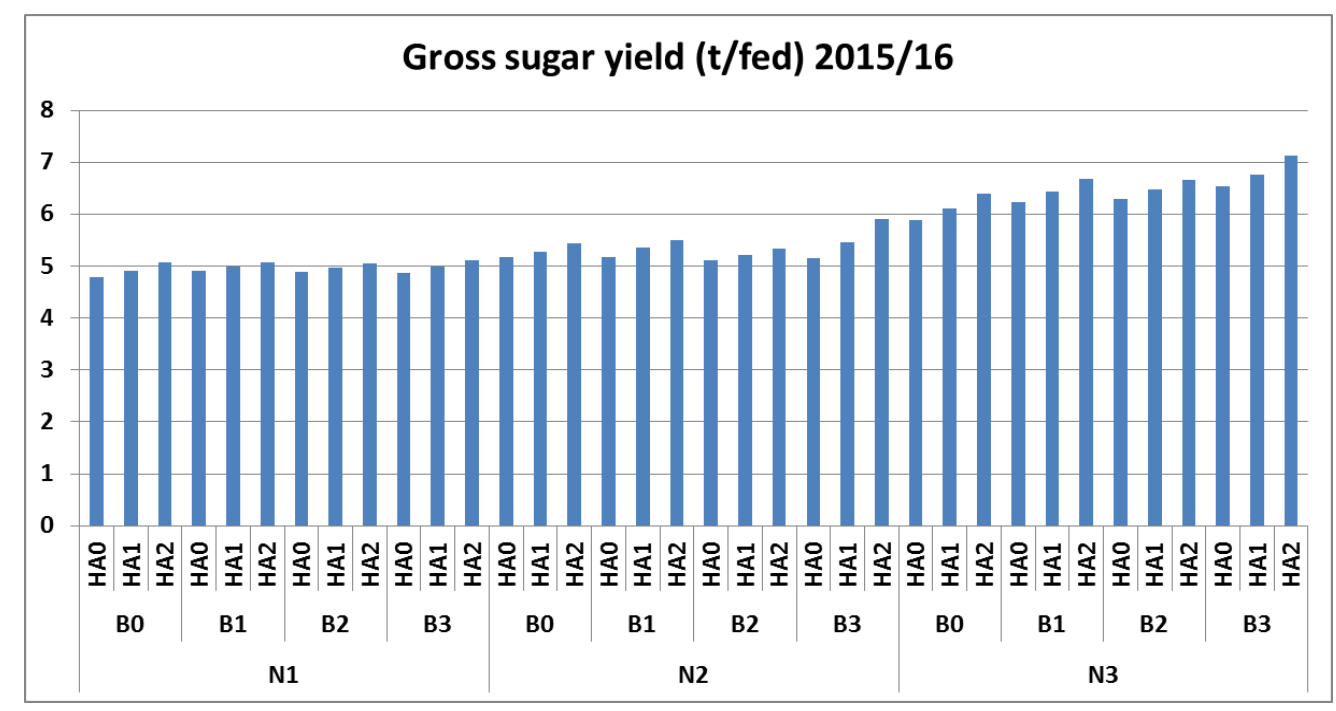

Fig. (2)

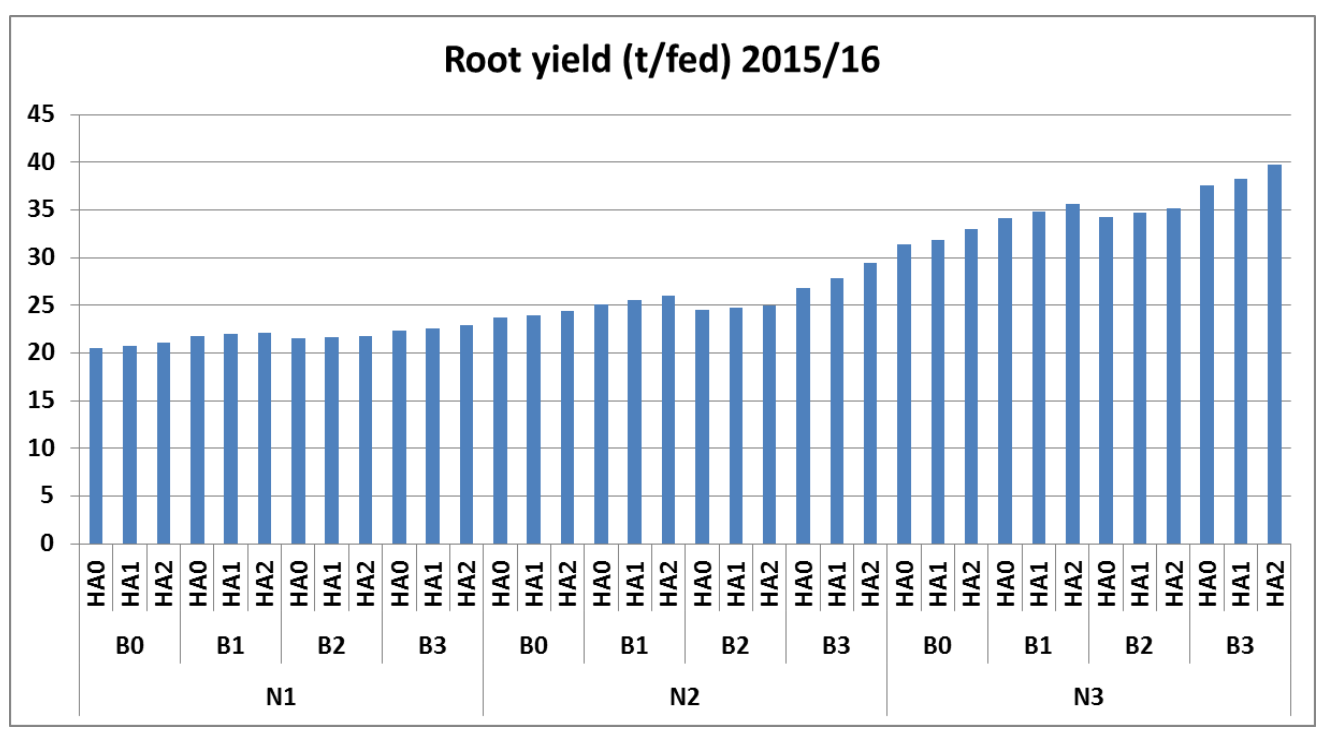

Fig. (3)

In figures (1, 2 and 3) where: $\mathrm{N}_{1}, \mathrm{~N}_{2}, \mathrm{~N}_{3}$ is 60, 90 and $120 \mathrm{~kg} \mathrm{~N} / \mathrm{fed}, \mathrm{B}_{0}, \mathrm{~B}_{1}, \mathrm{~B}_{2}$, $\mathrm{B}_{3}$ is uninoculated, rhizobactrein, phosphorein and dual inoculation, $\mathrm{HA}_{0}, \mathrm{HA}_{1}$, $\mathrm{HA}_{2}$ is 0,12 and $24 \mathrm{~g} / \mathrm{l}$, respectively.

while the differences in root diameter $(\mathrm{cm})$ and yield in terms of root, biological and gross sugar ( $\mathrm{t} / \mathrm{fed}$ ) in the second season due to the interaction among the three factors were significant. The highest root fresh weight $(2.17$ $\mathrm{kg} /$ plant), root yield (39.77 t/fed) and gross sugar yield $(7.13 \mathrm{t} / \mathrm{fed})$ which are

Fayoum J. Agric. Res. \& Dev., Vol. 31, No.2, July, 2017 
presented in Fig. (1, 2 and 3) were obtained by the higher level of mineral nitrogen fertilizer $120 \mathrm{~kg} \mathrm{~N} / \mathrm{fed}$ with application the mixture of rhizobactrein+ phosphorein with the higher level of foliar sprayed with humic acid $24 \mathrm{~g} / \mathrm{l}$.

\section{Regression analysis of yield and its attributes}

The results obtained in Table (4) clarify that there are four traits i.e. sucrose $\%$, root yield, root length and root fresh weight in the first season, while there are three traits i.e. root yield, sucrose and root fresh weight in the second one were significantly $(\mathrm{P} \leq 0.001)$ contributed to variation in gross sugar yield.

Generally, under the condition of this study, it could be recommended that fertilizing sugar beet with $120 \mathrm{~kg} \mathrm{~N} / \mathrm{fed}$ as mineral nitrogen fertilizer and using mixture of rhizobactrein+ phosphorein as biofertilization and sprayed with $24 \mathrm{~g} / 1$ humic acid, increased the productivity and quality of sugar beet plants.

\section{REFERENCES}

Aboshady Kh. A.; M. N. El-Said and M.F.M. Ibrahim (2009): effect of bacterial biofertilization and N-levels on yield and quality of sugar beet. J. Agric. Sci. Mansoura Univ. 34 (12): 10815- 10823.

Amin, Gehan A., Badr, Elham A. and M.H.M. Afifi (2013). Root yield and quality of sugar beet (Beta vulgaris L.) In response to biofertilizer and foliar application with micronutrients. World Applied Sciences Journal 27 (11): 1385-1389.

Attia, A.N. ; E.M. Said ; S.E. Seadh ; Samia S. El-Maghraby and M.E.M. Ibrahim (2011). Effect of sowing methods and weed control treatments on growth of sugar beet and weed characters under nitrogen fertilizer levels. J. Plant Production, Mansoura Univ. 2(6): 773-785.

Badawi, M.A. ; Kandil, A.A. ; M.S. Sultan ; A.N. Attia and S.E. Seadh (2004). Effect of planting dates, biofertilization and NK combination levels on: IIYield and quality of sugar beet. The $4^{\text {th }}$ Scientific Conf. of Agric. Sci., 7-9 Dec. 2004, Fac. of Agric. Assiut Univ. 747- 762.

Badr, Elham A. E. (2006): Effect of soil organic, bio-fertilization and plant density on yield and quality of sugar beet. Ph. D. Thesis, Fac Agric. Alex, Univ., Egypt.

Cakmakci, R.; F. Kantar and F. Sahin (2001). Effect of $\mathrm{N}_{2}$-fixing bacterial inoculation on yield of sugar beet and barley. J. of plant Nutrition and Soil Sci. 164(5): 527-531.

EL-gamal, I.S.; M. M. M. Abd El-Aal; S. A. El-Desouky; Z .M. Khedr and K. A. Abo Shady (2016). Effect of some growth substances on growth, chemical compositions and root yield productivity of sugar beet (Beta vulgaris L.) plant. Middle East Journal of Agriculture Research 5(2):171-185.

El-Hassanin, A.S., M.R. Samak, M. N. Shafika, A.M. Khalifa and I. M. Inas, (2016). Effect of Foliar Application with humic acid substances under nitrogen fertilization levels on quality and yields of sugar beet plant. Int.J.Curr.Microbiol.App.Sci. 5(11): 668- 680.

El-Sarag, E.I. (2009). Maximizing sugar beet yield, quality and water use efficiency using some agricultural practices under North Sinai conditions Bull. of Fac. of Agric., Cairo Univ. 60(2): 155-167.

Fayoum J. Agric. Res. \& Dev., Vol. 31, No.2, July, 2017 
EFFECT OF MINERAL, BIO FERTILIZATION, HUMIC ACID.......... 49

Gobarah, Mirvat E, Magda H. Mohamed and M. M. Tawfik (2010): effect of sources and rates of nitrogen fertilization on yield, quality and nitrogen utilization efficiency of sugar beet plant. Egypt. J. Agron., 2 (32): 123-138.

Gobarah, Mirvat E, Magda H. Mohamed, Manal F. Mohamed, M. M. Tawfik (2011). Potential of biofertilization for sustainable production of sugar beet (Beta vulgaris L.) in newly reclaimed sandy soil. Int. J. of Acad. Res. 3(6):120-125.

Gomez, K.A. and Gomez, A.A. (1984) "Statistical Procedures for Agricultural Research". Book John Willey and Sons Inc., New York.

Harvey, G.W and Dotton, J.V. (1993). Root quality and processing pp. 571-617. In The Sugar Beet Crop Science Into Practice, Edited by D.A. Cooke and Scatt Published 1993 by Chapman \& Hall. Edited by D.A. ISBN041225132.

Hozayn, M., M.M. Tawfik, H.M. Abd El-Ghany and A.M. Korayem, (2013).Effect of plant density on yield and sugar quality characteristics of sugar beet. J. Appl. Sci. Research 9(1): 1004-1009.

Kandil, A.A.; M.A. Badawi ; S.A. El-Moursy and U.M.A. Abdou (2002). Effect of planting dates, nitrogen levels and biofertilization treatments on: II- Yield, yield components and quality of sugar beet (Beta vulgaris, L.). J. Agric. Sci. Mansoura Univ. 27(11): 7257-7266.

Lauer, J.G (1995).Plant density and nitrogen rate effects on sugar beet yield and quality early in harvest. Agron. J. 87:586-591.

McGinnus, R.A. (1971). Sugar Beet Technology $2^{\text {nd }}$ ed. sugar beet development foundation, Fort., Color, U.S.A.

Mehdi S. S., P. Farzad, H.D. Hossein, M. Hamid, M. Majid and R.T. Mohamad (2013).Effect of intermittent furrow irrigation, humic acid and deficit irrigation on water use efficiency of sugar beet. Annals of Biological Research 4 (3): $187-193$.

Mekdad, A. A. A. (2015). Sugar beet productivity as affected by nitrogen fertilizer and foliar spraying with boron. Int. J. Curr. Microbiol. App. Sci. 4 (4): 181-196.

Mekdad, A.A.A. and M.M. Rady (2016). Response of Beta vulgaris L. to nitrogen and micronutrients in dry environment. Plant Soil Environ. 62 (1): 23-29.

Nemeata Alla, H .E. A.; E. A. E. Nemeata Alla and A. A. E. Mohamed (2014). Response of sugar beet to micronutrients foliar spray under different nitrogen fertilizer doses. Egypt. J. Agron. 36(2): 165 - 176.

Ouda, Sohier M.M. (2001). Response of sugar beet to N and K fertilizers levels under sandy soil conditions. Zagazig J. Agric. Res. 28(2), 275-297.

Ramadan, B.S.H. ; H.R. Hassan and Fatma, A. Abdou (2003). Effect of mineral and biofertilizers on photosynthetic pigments, root quality, yield components and anatomical structure of sugar beet (Beta vulgaris L.) plants grown under reclaimed soils. J. Agric. Sci. Mansoura Univ. 28(7): 5139-5160.

Rassam, G.; A. Dadkhah; A. K. Yazdi and Maryam Dashti (2015). Impact of humic acid on yield and quality of sugar beet (Beta vulgaris L.) grown on calcareous soil. Not. Sci Biol. 7(3):367-371.

Sahin F., Çakmakçi R. and F. Kantar (2004): Sugar beet and barley yields in relation to inoculation with $\mathrm{N}_{2}$-fixing and phosphate solubilizing bacteria. Plant and Soil. 265: 123-129.

Fayoum J. Agric. Res. \& Dev., Vol. 31, No.2, July, 2017 
Seadh, S. E. ; S. Farouk and M. I. EL-Abady (2007). Response of sugar beet to potassium sulfate under nitrogen fertilizer levels in newly reclaimed soils conditions. African Crop Science Conference Proceedings 8: 147-153.

Seydabadi, A. and M. Armin (2014). Sugar beet (Beta vulgaris L.) response to herbicide tank mixing and humic acid. International journal of biosciences 4(12): 339-345.

Shaban, KH.A. H.; Eman M. Abdel Fatah and Dalia A. Syed (2014). Impact of humic acid and mineral nitrogen fertilization on soil chmical properties and yield and quality of sugar beet under saline soil. J. Soil Sci. and Agric. Eng., Mansoura Univ. 5 (10): 1335 - 1353.

Shewate, S.R. ; P.V. Ghodke and A.S. Patil (2008). Effect of nitrogen levels and varieties on sugar beet growth, yield and quality. Cooperative Sugar 39(11): 29-33.

Stevens, W. B., A. D. Blaylock, J. M. Krall, B.G. Hopkins and J. W. Ellsworth (2007). Sugar beet yield and nitrogen use efficiency with preplant broadcast, banded or point-injected nitrogen application. Agron. J. 99:1252-1259.

Türkmen Ö., S. Demir, S. Ensoy and A. Dursun (2005). Effects of mycorrhizal fungus and humic acid on the seedling development and nutrient content of pepper grown under saline soil conditions. J. Biol Sci. 5(5): 568-574.

Zhang, J.X. ; L. Qiang ; X. Li Hua and G. Yu Zhu (2009). Effects of nitrogen fertilization on fibrous root distribution and activity in high yield sugar beet. Plant Nut. and Fertilizer Sci. 15(4): 904-909.

Zientara, M., (1983). Effect of sodium humate on membrane potential in internodal cells of Nitellopsis obtusa. Acta Societatis Botanicorum Poloniae 52: 271-277.

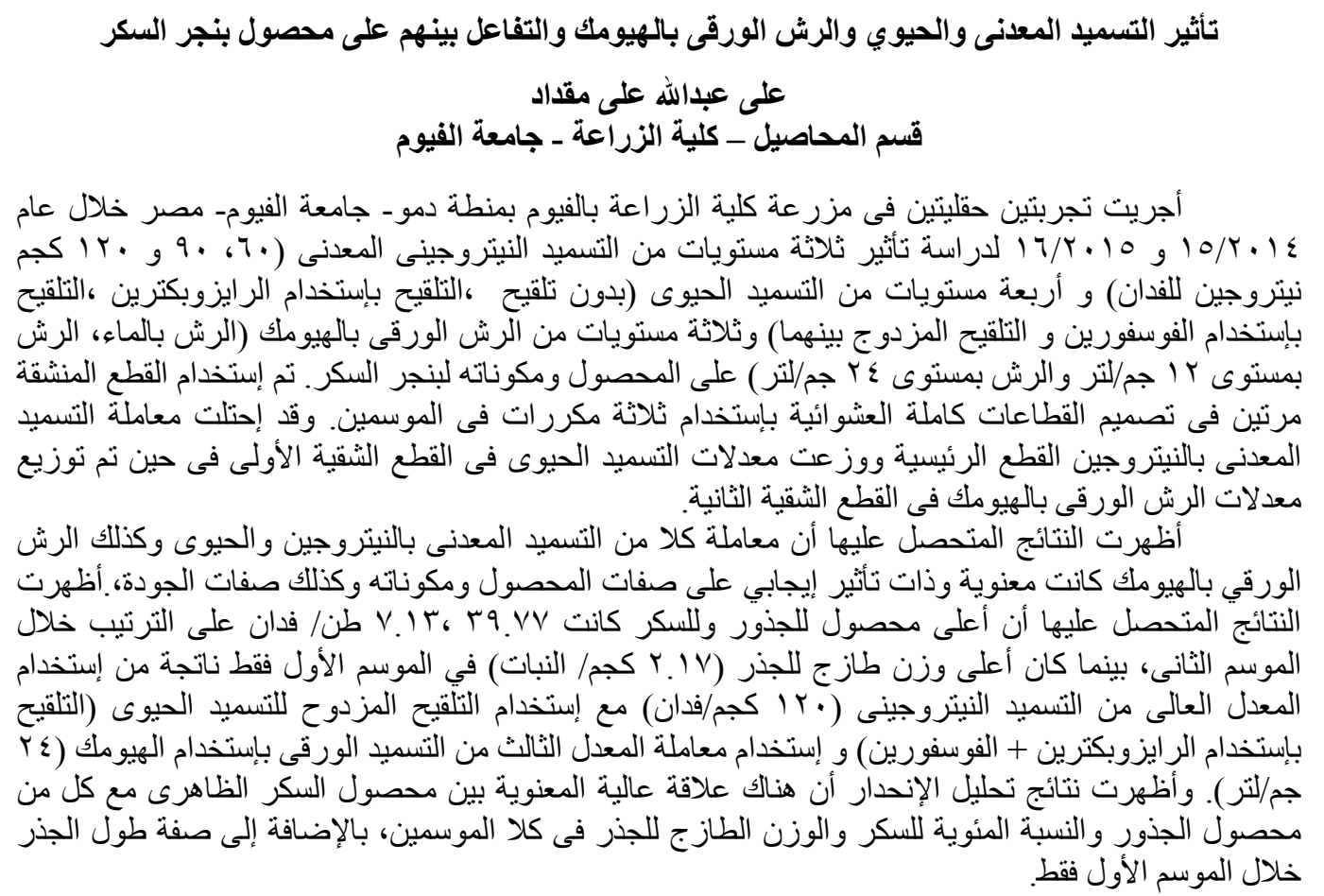

Fayoum J. Agric. Res. \& Dev., Vol. 31, No.2, July, 2017 